UDC 821.161.1

DOI https://doi.org/10.32838/2663-6069/2020.4-3/24

Zhaboruk I. A.

South Ukrainian National Pedagogical University named after K. D. Ushynsky

Gerkerova O. M.

South Ukrainian National Pedagogical University named after K. D. Ushynsky

Milova M. M.

International Humanitarian University

\title{
HISTORICAL ASPECT OF GENRE CATEGORY
}

In modern literary criticism there are plenty of different, sometimes entirely opposite points of view concerning the problem of genre, which is the evidence of its exceptional complexity and versatility. So some scholars define it as absolute chaos in this field. And still, we can single out two main opposite tendencies for understanding the nature of genre. Conventionally, one of them can be called formalistic, the other one-psychological.

The representatives of the formalistic approach see the sense of artistic creativity, first of all, in its form. This is the basic postulate of contemporary modernistic aesthetics. They believed that the task of an artist is to create a construction of an appropriate architecture. As to the content, it plays, in the view of the formalists, a secondary role, subordinate to the form.

In 1930-ies the main obstacle in the way of Soviet literary theorists in solving the problems of genre were the views of the, so called, vulgar sociologism. In their works they treated genre as a class category, merely ideological.

According to the psychological approach literature should be regarded as a specific, imaginative form of reflection and cognition of reality, which is, first of all, a result of social processes, while a particular literary work is a dialectical unity of form and content, content being a dominant feature with form playing an important part.

The existence of various treatments of genre category is the evidence of the fact that it is a really complicated theoretical problem. Analyzing the existing viewpoints, the authors make an attempt to formulate their own vision of the problem of genre as a certain type of literary production, formed in the process of historical development of literature and possessing relatively stable properties of form and content. Being a kind of a universal and specific instrument of artistic exploration of reality, genre imparts a character of a conceptual aesthetic whole to an individual work of literature. Most important regularities of literary process: the balance of form and content, author's conception, tradition and anticipation of readers, all stable and changeable peculiarities of literature are crisscrossed and reflected in genre.

Key words: category of genre, literature, fiction, literary work, formal approach, structuralism, inner structure, outer structure, typology.

Stating the problem. In modern literary criticism there are plenty of quite different, sometimes entirely opposite points of view about the problem of genre, which is the evidence of its exceptional complexity, and versatility. The patchwork of approaches to this question gave a good reason to St. Skwarczyńska to define the state of the genre theory as "the picture of absolute chaos in this field" $[6$, p. 30]. And still, in this chaos we can single out two main streams, two opposite tendencies for understanding the nature of genre. Conventionally, one of them can be called formalistic, the other one - psychological.

The purpose of the study is to analyze the existing views on the category of genre, and taking into account the most valuable thoughts and ideas, give our own definition of the category of genre for further practical analysis of specific literary works.

The analysis of the existing views on genre. The representatives of the formalistic approach (N. Pearson, R. Petsch, P. Wellek, O. Warren) see the sense of artistic creativity, first of all, in its form. This is the basic postulate of contemporary modernistic aesthetics. It was eloquently expressed by an American literary scholar N. Pearson - one of the most notable genre theorists. He believed that the task of an artist is to create a construction of an appropriate architecture. As to the content, 
it plays, in the view of the formalists, a secondary role, subordinate to the form. [4, p. 63] It is not at all accidentally that they gave up the term "content", substituting it by the term "material", or "the inner form" In fact, the content, in their understanding, is just a kind of form. According to R. Petsch, the "inner form" inevitably leads to the "outer form" [5, p. 91].

In line with this methodological attitude, the representatives of the formalistic approach treat the category of genre as a combination of purely formalistic characteristics, which perform in literature entirely constructive function, while the characteristics of the content are completely ignored.

Summarizing what had been said about the category of genre by the advocates of the formalistic trend, R. Wellek and O. Warren in their "Theory of Literature", gave their due to the vague rhetoric about content ("inner form" according to their terminology), and pointed out that their theory depends more on the "outer form", then the "inner form", and following this theory one could rather regard "Hudibras" written in octave, or a sonnet to be a kind of genre than a political novel because their classification concerned literature and not the classification of contents [8, p. 250].

The fullest expression of formalistic trend is the structuralism, which was widely spread in $50-60 \mathrm{~s}$ of the last century. The representatives of structuralism (R. Jacobson, R. Bart, T. Todorov) classify the genres of literary works according to the types of discourse, that is the way of structural organization of a literary text. The French structuralist T. Todorov gives detailed characteristics of the main components which determine the type of the text. According to T. Todorov these are, in particular, characteristic features of the speech register dominating in the literary text (its specificity or abstractness, mono- or polyvalence, degree of figurativeness, peculiarities of temporal and spatial text arrangement, "point of view" of representation and perception of the events described in the text, the manner of connection of separate episodes: framing, chaining, rotation) [21, p. 37-114]. Monoand polyvalence are understood as absence or presence of reference to another text. Structuralists attach particular importance to the "point of view" and approach to the artistic time for identifying the type and genre of a literary work. These principles are basic for the conception of genre of P. Hernadi. In his book "Beyond Genre" he singles out "points of view", as "author's", "interpersonal", "private", "dual", and also typical "types of discourse" (text structures), as lyrical, dramatic, narrative (epic), and "theme-based". The author believes that latter refers to textual arrangement of didactic and rhetoric character [2, p. 152-153].

Structural approach has certain advantages for solving specific genre problems as it operates material which is specific and particular for literature as a verbal art and is, to the least extent, subjected to speculation. But here the advantages are exhausted. The main and decisive drawback of this method is the fact that it extremely and improperly narrows the notion of genre, actually reducing it to the category of "technical" means of literature. It turns a relatively independent subject of study as a work of fiction into a metaphysically isolated, secretive entity, impersonal subjective text. Removing from a literary work everything which is not merely specific to it, ignoring multilateral connections of literature and history, social life, ideology, philosophy, etc., structuralism actually leads to the total loss of informative point of genre categories, and it serves us grounds to qualify the structural conception of genre as extremely formalistic.

There were also structuralists who tried to retain the thread which leads to the revealing the spiritual significance of the work of fiction, they regard a text not as, a secretive entity, but it leads to a complex of life's problems. Humanistic origin which is always laid in fiction does not drawn and vanishes in statistic figures and formulae. Such approach can be found in the works of M. Lotman, B. Uspensky, J. Slawńsky, K. Konrad. But even this approach it does not seem possible to solve the problem of genre, as it ignores such important aspects of the literary work as the character of its composition, specific nature of the conflict which lies in its foundation.

In contrast to the formalists who treats genre as a mere formal category, the representatives of psychological direction, K. Burk [1], E. Bentley [10] totally ignore the form, connecting the genre diversity of the literary works with the character of psychological relations of people to the world around them, with various kinds of human emotions, inclinations and, even, to a certain extent, with one's philosophy of life. Thus, they disproportionately widen the frames of the notion of genre, bringing it out of the sphere of literary criticism, dissolving it in purely psychological and philosophic categories. For example, P. van Tiegen explains recurring types of literary works by nothing else but recurring types of literary prodigies, on the one hand, and recurring peculiarities of the readers, on the other hand.

The ideas of E. Bentley who regards the category of genre as a peculiar way of manifesting and fulfilment of human inclinations, taking into account the fact that 
different types of literary works can bring up various emotions for readers (e.g., pity, fear, indignation, fairness etc.) [10]. K. Burk widens the frames of the genre category still more by basing genre classification of literature on the principle of accepting or rejecting the world. To the first group of fiction, which increases the readers' accepting the world (he calls them "the system of acceptance"), he attributes epic, tragedy, comedy, and humor in general, while elegy, satire and burlesque to the second.

There is also nihilistic attitude to genre which we find in the theoretical works of B. Krotsche, who declared genre to be "the most significant misconception" [14, p. 11-43]. He explains his rejection of genre by "indivisibility" of literature (and a separate literary work) on the one hand, and by the individuality and uniqueness of art, which excludes their subordination to common rules. He belonged to the psychological wing of literary criticism, for him literature was nothing more but intuitive psychological expression of a writer, and, at the same time, a specific linguistic phenomenon.

B. Krotsche's treatment of genre category was later developed in the academic writings of his American disciple J. Spingharn. According to the letter, the poets just express themselves and the expression is nothing more but their form. So, we cannot speak about three, or ten, or a hundred of literary genres. They are as many as there are poets $[25$, p. 51$]$.

Soviet genre theorists being actually torn from the western ideas and confined to the limits of Marxist ideology had their own difficult road in search for solving these problems.

In the 20s, however, the most popular school was formal. The representatives of this direction (B. Tomashevsky, V. Shklovsky, B Eichenbaum), as well as their western colleagues understood genre simplistically, reducing it to a certain combination of structural techniques, independent of the content of the literary work. At the same time there was a tendency of overcoming the one-sided formalistic view of literature and genre, particularly, in the works of V. Zhyrmunsky and Y. Tynyanov.

As a whole, V. Zhirmunsky shared the ideas of the formal school, though with an essential correction. In his famous book "Byron and Pushkin" the scholar expressed an idea which marked the appearance of a qualitatively new approach to the treatment of genre in the Soviet literary criticism. The core of this conception is the recognition of an important fact that the nature of genre cannot be restricted to formal components only, because, as he emphasizes, "no matter how we may sublimate the notion of "genre", no matter how hard we may try to give it a "formalistic" definition, the essential factors of "content" will always remain in it" [13, p. 200].

An original conception was put forward by Y. Tynyanov in 1920s. Y. Tynyanov focused on the problems of genre and his work was rather fruitful. In his theoretical views he adhered the principles of the formal school. In a work of fiction as an object of study he was interested only with its formal aspect, and particularly - the linguistic structure of the text, because, according to him "life (in the sense of reality shown in the work of fiction) correlates with literature only through its speech side. The same is the correlation of literary types and the life" [23,p.278]. Hence the criteria of genre classification by Y. Tynyanov lie in the structure of the literary text. This idea of the scholar was developed by structuralists and became the foundation of their theory. At the same time genre for Y. Tynyanov is not a mechanistic combination of constructive elements in this or that compatibility, but a rather mobile, dynamic system in which all components are correlated by functional congruence. Moreover, the factors which are part of the genre system are not equal - one of them (sometimes several) is always highlighted and acquires a character of attitude or dominance which functionally subordinates the rest of the factors inside the genre. Highlighting a new factor instead of the previous one is the main reason of changeability, or rather, the substitution of one genre by another, since, according to the conception, the changes inside the genre - are "not an orderly evolution, but a leap, not a development, but a displacement" [23, p. 256]. In understanding the genre as a dynamic system, which enters the system of literature by means of a separate work of fiction lies the significance of Y. Tynyanov's ideas about the category of genre.

In 1930s the main obstacle in the way of Soviet literary theorists in solving the problems of genre were the views of the, so called, vulgar sociologism. In their works they analyzed not the category of genre as such, not its aesthetic nature, they were much more interested in dependence of genre on sociologic factors. Extremely simplifying the dialectical relationship between the underlying structure and the superstructure, absolutely ignoring the specificity of literature as an imaginative form of cognition of reality, the representatives of this direction (V. Fritsche, V. Pereversev) treated genre as a class category, merely ideological believed that any literary genre is closely connected with the basic image of a class at the current stage of historic existence of the class, its "being" and "mind", translated into the language of artistic creativity. 
The development of the problem of genre intensified particularly in the post-war period. By this time, most mistakes of formal and sociological directions were overcome. The Soviet theorists of literature were making an attempt to develop clear methodological principles for art and literary analysis, which should correspond to Marxist ideology.

According to these principles, literature should be regarded as a specific, imaginative form of reflection and cognition of reality, which is, first of all, a result of social processes, while a particular literary work is a dialectical unity of form and content, content being a dominant feature with form playing an important part. This fundamental methodological approach is basic for most literary genre conceptions of the later Soviet period. Even now it hasn't lost its validity. We must admit that it bridges the gap between different theories, though it doesn't eliminate differences between them.

Let us highlight a few basic theoretical conceptions of genre of the period. It is, first of all, the conception of V. Kozhinov and D. Gatchev. It consists of viewing the genre as "a meaningful form". The authors presented it in the second volume of academic "Literary Theory" [19].The essence of theirconception is theunderstanding of genre as a "holistic arrangement of formal properties and features" of a separate work of fiction, possessing its peculiar content. This "peculiar content" is distinctly visible only at the early period of genre genesis that is at the early stage of its development, when the genre was still "directly meaningful" (for the novel it is the XVI - XVII century). With regard to the new, and furthermore the newest literature, genre, according to the authors of this conception, manifests itself in the form of "petrified" ("solidified") content, turned into a "literary construction", so to reveal the inner facet of genre, its "real complexity and clarity we can only in the process of analyzing the specific character and the properties of fiction" [19, p. 19].

Such scholars as G. Pospyelov, L. Tchernyets, andA. Esalnektreatthecategoryofgenrefromadifferent perspective. While V. Kozhinov and D. Gatchev treat genre as a category of "the meaningful form" G. Pospyelov understands it as a category of content. Having singled out and distinguished between the conceptions "of the inner genre" and "the outer genre", he acknowledges the former of the two components to be determining, thus denying any essential influence of the form on the character of genre. By the "outer genre" G. Pospyelov means such types of fiction which have been formed in the course of time. These are: a fairy tale, a poem, a short story, a story, a novella, a comedy, an elegy, etc. The peculiarities of genre cannot be searched only in the specific features of these literary types as they have been evolving in accordance with the evolution of their ideological filling. As for the "inner genre", it is understood by G. Pospyelov, as historically arising principles of interpretation of personages. Since literature is primarily "the science of man", and the main object of representation in literature is the man in his diverse social and domestic connections (man and nature, man and society, man in his own self) then it is the character of the personages (or the main heroes) and, to be more exact, the type of relations of man and society determines according to G. Pospyelov, the essence of genre and makes this category typological. However, it should be pointed out that G. Pospyelov does not connect a literary genre and a literary type by the logic of collateral subordination. The statement about genera of literature having their own genres, and genres having their own types is, according to G. Pospyelov, not correct. In view of this, he classifies epic, lyrics and drama by the same principles.

Some of G. Pospyelov's important ideas are shared by L. Timofeyev, who also believes that a certain type of depicting a personage forms the basis for genre definition. In his creativity a writer turns to various ways of human behavior, hence is the variety of ways of depicting a human character. L. Timofeyev believes that it explains the fact that some authors turned to various genres [20, p. 357].

The third and the most popular point of view among Soviet genre theorists is the conception that genre is actually a dialectical unity of the most essential features of form and content. One of the most steadfast advocates of this point of view is academician D. Lichatchyov. In one of his studies he attributed genre to one of those themes which occupy both the sphere of form and the sphere of content [16, p. 24]. If there are certain disputes between the supporters of this idea, they concern some details only but not its essence.

There are also interesting attempts to look upon the problem of genre in its correlation with the problem of the artistic integrity of the literary work. In this respect the conception of N. Leiderman is rather interesting. He understands genre as "a historically developing type of a steady structure of a literary work, which arranges all its elements into a system which creates a holistic image of the world" [15, p. 26].

The existence of various treatments of genre category is the evidence of the fact that it is a really complicated theoretical problem. Neither European, nor Soviet literary theorists have found answers to its numerous problems. Such is the situation in the theory of literature which has been formed in the last quarter of the XX century 
and is prevailing up to now. Hence numerous difficulties in analyzing the genre nature of a particular work of fiction. So if a literary critic has an objective of this kind, he must, first of all, look into the theory, reflect on the existing conceptions and determine his own attitude towards genre and consequently stick to it in the process of the analysis.

The notion of genre was finally established in criticism when continuity in literary creativity became evident, that is when sufficient material was accumulated to understand that there exist many common features in the books of various authors, no matter when and where they had been created. This important circumstance which characterizes one side of the literary process was recorded in the numerous attempts of defining the category of genre. One of such attempts was made by B. Tomashevsky who defined genre as the groups of similar works. "Each literary work, to a greater or lesser extent, imitates the earlier literature. If it were not for this imitation all works of fiction would be radically different and it would be impossible to group them into genres" [22, p. 96].

A similar idea was expressed by V. Shklovsky, who defined genre as a specific type of literary unity whose roots should be sought in literary traditions: "There exist different types of literary tradition; each has its own connections and its own grounding of these connections. The similar connections are called genres" [27, p. 188-189].

Being a type of literary unity, genre possesses a certain structural stability, and is, according to M. Bachtin, "artistic memory in the process of literary development which can ensure the unity and indivisibility of this development [9, p. 179]. At the same time, the stability of genre is a relative concept. It is known that one of the most essential features of a literary work is its uniqueness caused by uniqueness of its specific historical content on the one hand and by inimitable originality of the author's talent on the other. This unique character every time puts an impact on the genre of the literary work. That is why, genre is always "different, it is old and, at the same time it is new. Genre revives and renews itself with every other stage of the development of literature, with every individual work within the frames of this genre" [9, p. 179].

A decisive factor in genre development is the conflict between the tendency to conservation of the genre nature (the result of the imitation effect in art) and the constant desire for denying it and renewing itself. Thus, this process corresponds to the law of "conservation and negation". There is no enrichment without conservation, at the same time development is impossible without negation $[12$, p. 28]. The experience of the past facilitates individual creativity, without the support of the past experience "there would forever remain a naked man on the bare land" [11, p. 30]. Here is the explanation of the fact that we find common and repeated elements in every unique work of art. At the same time every writer, in spite of his tendency to imitate (this tendency is different in each individual case) due to the influence of new circumstances, his individuality and his own artistic view of the world, always contributes something new to literature. Thus, we can state that genre is immediately correlated with the categories of traditions and innovation. These traditions play an exceptional part in the progressive development of literature.

The author's approach. The category of genre is closely connected with the category of integrity of a literary work. It is widely recognized that genre, first of all, characterizes a work of literature as a completed whole. M. Chraptchenko had every reason to say: "In case when the type of structural arrangement of a text is regarded, we characterize its genre" [25, p. 203]. It is connected with another important quality of genre - its complexity, heterogeneity. In this category the most important pattern of creativity - the law of dialectic unity of form and content, without taking it into consideration, it is absolutely impossible to understand the essence of this most complicated entity of form and content.

We agree to this view of genre as a category which unites both formal and informative features of the work of fiction.

The form contains, first of all, the outer, structural qualities of genre, which can easily be found in a literary work. To them we attribute characteristic features of composition, type of narration, and also a definite, steady complex of artistic means and devices. As for the content, one should look for the inner, deep (underlying) features of genre, connected with the peculiarities of the moral and aesthetic message of the work of art. We should not forget about such components of a literary work as a plot, characters, which, actually, possess both formal and informative features. Depending on the aspect of viewing, any of these two components may come to the fore.

Conclusions. So, the category of genre should be understood as a certain type of literary production, formed in the process of historical development of literature and possessing relatively steady properties of form and content. Being a kind of a universal and specific instrument of artistic exploration of reality, genre imparts a character 
of a conceptual aesthetic whole to an individual work of literature. Most important regularities of literary process: the balance of form and content, author's conception, tradition and anticipation of readers, all stable and changeable peculiarities of literature are crisscrossed and reflected in genre.

To our firm belief, the analysis of genre structure of a particular piece of fiction acquires a "universal character". In fact, it is the analysis of the ideas and artistic value of a work of fiction, whose aim is to understand its intellectual and aesthetic uniqueness on the one hand and to establish its genetic connections, the degree of kinship with other literary works, and, thus, to find out its place in the literary process of a particular historic period.

As it has already been noted, different components of a literary piece may act as genre-forming factors, but one of them always appears dominant, having determining impact on the specificity of genre.

Having a task to look into the specific nature of genre of a concrete work of literature, we usually advance from in the direction from its individual essence to the general that is to its genre nature. This is quite natural because "the genre character of the whole should be searched in itself - as a backbone of an individual artistic system", as an "inner form" based on the conflicts rooted in all kinds of art" [18, p. 67].

However, this "inner form" contains elements which have common features with the correspondent elements of other literary pieces. So a quite natural demand for comparing such elements is to reveal their functioning in a particular work of literature, and, besides to find out the sources of the similarity. It is here that the starting point for understanding genre sources of a work of fiction, that are in line of a certain artistic tradition could be found. It is important to find these genre sources as "the better and more detailed we know the genre contacts of an artist, the deeper can we penetrate into the peculiarities of its genre form and understand the interaction of originality and tradition in it better" $[9$, p. 269].

\section{List of literature:}

1. Burk K. Attitudes Towards History. Los Angeles : University of California Press, 1984. 448 p.

2. Hernadi P. Beyond Genre. New Direction in Literary Criticism. London : Comell Univ. Press, 1987. 270 p.

3. Pearson N. Literary Types or a Defense of Polonius. English Institute Annal. 1940. Vol. 1. P. 24.

4. Petsch R. Vissen und Formen der Erzalkunst. Halle, 1942.

5. Skwarczynsska S. Wstęp do nauki o literaturze. T. 3. Ł Warszawa, 1965. $412 \mathrm{~s}$.

6. Wellek R. Theory of Literature: $1 \mathrm{~kg}$ Limited, $2018.420 \mathrm{p}$.

7. Бахтин М. Проблемы поэтики Достоевского. Москва : Советская Россия, 1979, 318 с.

8. Бентли Э. Жизнь драмы. Москва : Айрис-пресс, 2004. 416 с.

9. Благой Д. О традициях и традиционности. Традищия и история культуры. Москва : Наука, 1978. С. 28-37.

10. Бушмин А. Преемственность в развитии литературы. Ленинград : Художественная литература, 1978. $223 \mathrm{c}$.

11. Жирмунский В. Байрон и Пушкин. Ленинград : Наука, 1978. 424 с.

12. Кроче В. Эстетика как наука о выражении и общая лингвистика. Ч. І. Москва, 1920. 172 с.

13. Лейдерман Н. К определению категории жанра (Жанровая доминанта и носители жанра). Проблемь жанра в англо-американской литературе XIX-XX веков: научные труды Свердловского пединститута. Свердловск, 1976. Сб. 250. Вып. 2. С. 3-28.

14. Лихачев Д. Принцип историзма в изучении содержания и формы литературного произведения. Русская литература. 1965. № 1. С. 16-33.

15. Поспелов Г. О типологическом изучении литературы. Проблемы типологии русского реализма. Москва : Наука, 1969. С. 81-123.

16. Тамарченко Н. О жанровой структуре «Преступления и наказания» Ф. Достоевского. Проблемы жанра в истории русской и зарубежной литератур. Кемерово, 1976. С. 18-32.

17. Теория литературы. Основные проблемы в историческом развитии. Кн. 2 : Роды и жанры литературы. Москва : Наука, 1964. 486 с.

18. Тимофеев Л. Основы теории литературы. Москва : Просвещение, 1971. 462 с.

19. Тодоров Ц. Поэтика. Структурализм. «За» и «против». Москва : Прогресс, 1975. С. 37-114.

20. Томашевский Б. Краткий курс поэтики. Ленинград : Госллитиздат, 1928. 132 с.

21. Тынянов Ю. Поэтика. История литературы. Кино. Москва : Наука, 1974. 575 с.

22. Уиллек Р., Уоррен О. Теория литературы. Москва : Прогресс, 1978. 324 с.

23. Храпченко Н. Типологическое изучение литературы и его принципы. Проблемы типологии русского реализма. Москва : Наука, 1969. С. 82-89.

24. Чернец Л. К типологии жанров по содержанию. Вестник МГУ. Филология. 1969. 
25. Шкловский В. Повести о прозе. Москва : Художественная литература, 1966. Т. 335.

26. Эсалнек А. К вопросу о специфике романа. Научные доклады высшей школы. Серия «Филологические науки». 1968. № 5.

\section{Жаборюк І. А., Геркерова О. М., Мілова М. М. ІСТОРИЧНИЙ АСПЕКТ КАТЕГОРІї ЖАНРУ}

У сучасному літературознавстві існує безліч різних, часом цілком протилежних точок зору щодо проблеми жанру, щчо є свідченням ї̈ виняткової складності та багатогранності. Отже, деякі вчені визначають його як абсолютний хаос у цій галузі. Однак все ж таки ми можемо виділити дві основні протилежні тенденції розуміння природи жанру. Умовно один з них можна назвати формалістичним, інший - психологічним.

Представники формалістичного підходу бачать сенс художньоїтворчості насамперед у його формі. Це основний постулат сучасної модерністської естетики. Вони вважали, щуо завданням художника є створення конструкиії відповідної архітектури. Щодо змісту, то він, на думку формалістів, виконує другорядну роль, підпорядковану формі.

У 1930-х роках головною перешкодою на шляху радянських теоретиків літератури під час вирішення жанрових проблем були погляди так званого вульгарного соціологізму. У своїх роботах вони трактували жанр як класову категорію, лише ідеологічну.

Відповідно до психологічного підходу літературу слід розглядати як специфічну, образну форму відображення та пізнання дійсності, яка є насамперед результатом соціальних процесів, тоді як певний літературний твір - це діалектична єдність форми та змісту, де зміст є домінуючою рисою форми, яка відіграє важсливу роль.

Існування різноманітних підходів до категорії жанру свідчить про те, щзо ие є справді складною теоретичною проблемою. Аналізуючи наявні точки зору, автори роблять спробу сформулювати власне бачення проблеми жанру як певної категорії літератури, що формується в процесі історичного розвитку літератури та володіє відносно стабільними властивостями форми та змісту. Будучи своєрідним універсальним і специфічним інструментом художнього дослідження реальності, жанр надає характеру концептуального естетичного иілого окремому літературному твору. Найважливіші закономірності літературного процесу, зокрема збалансованість форми та змісту, авторська концепиія, традииія та очікування читачів, усі стабільні та мінливі особливості літератури, перетинаються та відображаються у жанрі.

Ключові слова: категорія жанру, література, художня література, літературна творчість, формальний підхід, структуралізм, внутрішня структура, зовнішня структура, типологія. 